doi: 10.18484/2305-0047.2017.1.44

V.Y. KHRYSHCHANOVICH ${ }^{1}$, P.Y. VERSHININ ${ }^{2}$, A.V. BOLSHOV ${ }^{1}$, S.I. TRETYAK ${ }^{1}$, E.I. KUZMENKOVA ${ }^{3}$, A.M. PISARENKO ${ }^{4}$, E.V. KHODOSOVSKAYA ${ }^{1}$, T.S. KOLESNIKOVA ${ }^{1}$, O.O. RUMMO ${ }^{2}$

\title{
ALlOTRANSPLANTATION OF CULTURED PARATHYROId CELLS FROM A LIVING UNRELATED DONOR TO A KIDNEY TRANSPLANT RECIPIENT: THE FIRST CLINICAL OBSERVATION
}

\author{
EE "Belarusian State Medical University" ', \\ ME “The 9 $9^{\text {th }}$ City Clinical Hospital”, Minsk ${ }^{2}$, \\ SE "Republican Center of Medical Rehabilitation and Balneotherapy” 3 , \\ ME "Minsk City Clinical Oncologic Dispensary" ${ }^{4}$, \\ The Republic of Belarus
}

Цель. Продемонстрировать возможность успешного лечения послеоперационного гипопаратиреоза тяжелой степени тяжести путем аллотрансплантации культивированных паратироцитов реципиенту с почечным трансплантатом.

Материал и методы. Реципиентом паратиреоидного аллотрансплантата была 37-летняя женщина с почечным трансплантатом и гипопаратиреозом тяжелой степени тяжести на фоне интенсивной заместительной терапии. Симптомы тетании, высокая судорожная готовность (симптомы Труссо, Хвостека), крайне низкие показатели общего/ионизированного кальция (1,71/0,98 ммоль/л) и паратгормона $(1,7$ пг/ мл) в периферической крови явились показанием к паратиреоидной аллотрансплантации. В толщу левой плечелучевой мышцы реципиента имплантировали $21 \times 10^{6}$ культивированных паратироцитов, полученных от живого неродственного донора (62-летней женщины) с вторичным гиперпаратиреозом. Выбор места для паратиреоидной аллотрансплантации обусловило отсутствие артериовенозной фистулы на стороне пересадки. Иммуносупрессивная терапия включала прием 150 мг/сутки циклоспорина, 720 мг/сутки микофеноловой кислоты, 6 мг/сутки метилпреднизолона.

Результаты. В послеоперационном периоде осложнений вмешательства, местных и общих побочных эффектов на паратиреоидный клеточный аллотрансплантат отмечено не было. Через 1 месяц после пересадки паратироцитов наступила клинико-лабораторная компенсация гипопаратиреоза: концентрация паратгормона возросла до 14,7 пг/мл и достигла максимального значения (61,7 пг/мл) через 3,5 месяца. На протяжении 6-месячного периода наблюдения судорожный синдром не возникал, симптомы Труссо и Хвостека купировались, объем пероральной заместительной терапии существенно уменьшился, исчезла потребность в парентеральном введении солевых растворов кальция. Через 6 месяцев после пересадки пациентка ведет привычный образ жизни и принимает per os 0,5 г кальция в сутки.

Заключение. Комбинированная аллотрансплантация трупной почки и культивированных паратироцитов, выделенных из гиперплазированной паратиреоидной ткани живого неродственного донора, является эффективным методом лечения перманентного гипопаратиреоза тяжелой степени тяжести у пациентов, нуждающихся в органной трансплантации с последующей иммуносупрессивной терапией.

Ключевые слова: аллотрансплантация паратироцитов, почечный трансплантат, интенсивная заместительная терапия, послеоперационный гипопаратиреоз, гиперплазированная паратиреоидная ткань, иммуносупрессивная терапия, послеоперационные осложнения

Objectives. To demonstrate the possibility of successful treatment of a severe postsurgical hypoparathyroidism by the cultured parathyrocyte allotransplantation to a kidney transplant recipient.

Methods. A 37-year-old female with the kidney transplant and a severe postsurgical hypoparathyroidism on the background of intensive replacement therapy was a recipient of parathyroid allograft. The indications for parathyroid autotransplantation include symptoms of tetany, high convulsive readiness (Chvostek's and Trousseau's signs), extremely low rates of total/ionized calcium $(1,71 / 0,98 \mathrm{mmol} / \mathrm{L})$ and parathyroid hormone $(1,7 \mathrm{pg} / \mathrm{ml}) \mathrm{in}$ the peripheral blood. Culture $\left(21 \times 10^{6}\right)$ of parathyroid cells obtained from a living unrelated donor $(62$-year-old female) with the secondary hyperparathyroidism was implanted into the recipients' left brachioradialis muscle. Site selection for parathyroid allograft was conditioned by the absence of arteriovenous fistula on the side of the transplantation. Immunosuppressive therapy consisted of $150 \mathrm{mg} /$ day of cyclosporine, $720 \mathrm{mg} /$ day of mycophenolic acid, $6 \mathrm{mg} / \mathrm{day}$ of methylprednisolone.

Results. No postoperative complications of the intervention, local and general side effects on the parathyroid cell allograft were observed. Clinical and laboratory improvement of hypoparathyroidism occurred 1 month after the transplantation: parathyroid hormone concentration increased up to $14,7 \mathrm{pg} / \mathrm{ml}$ and reached a maximum value $(61,7$ 
$\mathrm{pg} / \mathrm{mL}$ ) after 3,5 months. No convulsions were observed over a 6-month follow-up, Chvostek's and Trousseau's signs were stopped, the amount of oral substitution therapy significantly reduced, and there was no more need for parenteral administration of calcium salt solutions. Six months after transplantation a patient led a very active life and took per os $0,5 \mathrm{~g}$ /day of calcium.

Conclusion. Combined allotransplantation of cadaveric kidneys and cultured parathyroid cells obtained from the hyperplastic parathyroid tissue of a living unrelated donor is considered to be an effective treatment of permanent severe hypoparathyroidism in patients who need the organ transplantation with subsequent immunosuppressive therapy.

Keywords: parathyroid cells allotransplantation, kidney transplant, intensive substitution therapy, surgical hypoparathyroidism, hyperplastic parathyroid tissue, immunosuppressive therapy, postoperative complications

Novosti Khirurgii. 2017 Jan-Feb; Vol 25 (1): 44-52

Allotransplantation of Cultivated Parathyrocytes from a Living Unrelated

Donor to a Kidney Transplant Recipient: the First Clinical Observation

V.Y. Khryshchanovich, P.Y. Vershinin, A.V. Bolshov, S.I. Tretyak, E.I. Kuzmenkova,

A.M. Pisarenko, E.V. Khodosovskaya, T.S. Kolesnikova, O.O. Rummo

\section{Introduction}

Secondary or tertiary hyperparathyroidism is the most frequent cause of hypercalcemia in patients with the terminal chronic kidney disease (CKD). Subtotal parathyroidectomy is a safe and efficacious treatment for hyperparathyroidism after which the risk of a severe hypercalcemia development occurs in less than $1-2 \%$ of the operated patients. [1]. The severity of the symptoms specific to hypocalcemia can vary widely and sometimes even be life-threatening in case of a generalized convulsive seizure, refractory heart failure, laryngospasm. Being an extremely severe complication, hypocalcemia requires lifelong calcium (high doses) and vitamin D3 replacement therapy (including intravenous injections) and in the distant future it may cause the development of cataracts, basal ganglia calcification, extrapyramidal signs, nephrocalcinosis and renal failure. Besides, the need of daily large number drug intake and the requirement of frequent parenteral administration of calcium salt solutions negatively affect the quality of patients' life.

Until now, the physiologic and simultaneously safe method of successful parathyroid allotransplantation without recipient's immunosuppression has not been developed yet.It should be noted that in some countries parathyroid hormone (PTH), commonly used for other indications, is now available for the treatment of patients with HPT. In the available literature of the recent century, it was presented in the literature in the form of few reports of cases from practice (with/without reciepient's immunosuppression), as one of the treatment methods of permanent HPT (Table 1) [2-21]. However, as demonstrated by S. Wells et al. [22], it was enough to perform autotransplantation of several fragments of the hypertrophied parathyroid gland (PTG) without its direct revascularization for the successful prevention of permanent HPT after total parathyroidectomy. In 1974, S. Wells et al. used a parental allograft (2 parathyroid glands), which were obtained from father and transplanted to son with kidney transplant. [7].

Objective. To demonstrate the possibility of successful treatment of a severe postsurgical hypoparathyroidism by the cultured parathyroid cells allotransplantation to a kidney transplant recipient.

\section{Clinical observation}

The recipient of a parathyroid cell allograft was a woman (aged 37 years), since childhood suffering from a chronic glomerulonephritis led to nephrosclerosis and as a result being on the scheduled hemodialysis therapy for the recent 18 years. Against the background of the terminal cronic kidney disease stage and 11 years after starting dialysis the secondary hyperparathyroidism has developed and it may serve as an indicator of the total parathyroidectomy.After 6 months the logical outcome of a radical surgery on parathyroid gland (PTG) was a severe postoperative hypocalcemia that developed in permanent and required orally per day calcium supplementation (up to $4 \mathrm{~g}$ ), cholecalciferol (up to $1800 \mathrm{IU})$, calcitriol $(1,25 \mathrm{mcg})$, and frequent (1-2 times per week) intravenous injections of 2-4 $g$ of calcium gluconate for the seizures relief.

In August 2015, the heterotopic transplantation of the cadaveric kidney was performed and the immunosuppressive therapy was prescribed (cyclosporine $150 \mathrm{mg} /$ day, mycophenolic acid $720 \mathrm{mg} /$ day, methylprednisolone $6 \mathrm{mg} /$ day). 5 months after transplantation a regular laboratory and instrumental examination showed relatively satisfactory kidney transplant function. Serum urea indices ranged from 9,8 to $11,8 \mathrm{mmol} / \mathrm{l}$, creatinine - from 141 to 184,8 micromol/1; glomerular filtration rate - from 29,4 to $30,8 \mathrm{~mL} /$ minute. Cyclosporine blood concentration ranged within $71,2 \mathrm{ng} / \mathrm{ml}$. At the same time despite the maximum possible (for calcitriol) HPT replacement therapy application no current method is able to reverse or delay the disease's progress. Against the background of very low rates of total / ionized calcium $(1,71 / 0,98 \mathrm{mmol} / \mathrm{l}$; normal range 2,15-2,55/1,12-1,32 $\mathrm{mmol} / \mathrm{l})$ and parathormone $(17 \mathrm{pg} / \mathrm{mL}$; normal range of $15-65 \mathrm{pg} / \mathrm{ml}$ ) in the peripheral blood, the symptoms of tetany and high convulsive readiness remained 
(Chvostek's 4+ and Trousseau's signs). In addition, the patient complained of paresthesia, muscle weakness and fasciculations, fatigue during even little physical or mental stress. In December 2015, taking into account an extremely severe course of the postoperative HPT, refractory hypocalcaemia, the patient's young age and persistent immunosuppression, it was decided to perform allotransplantation of the cultured parathyroid cells extracted from the parathyroid tissue of a living-unrelated donor (a woman of 62 years old) with the secondary hyperparathyroidism. There was no donor-recipient compatibility regarding $\mathrm{ABO}-$ phenotype and $\mathrm{Rh}$-factors - A (II) $\mathrm{Rh}+$ vs $\mathrm{O}$ (I) R-. HLA-typing was not performed.

Under the local anesthesia the skin and subcutaneous tissue were dissected (over $2 \mathrm{~cm}$ ), the fascia of the left humeroradial muscle was exposed, 21 of the cell suspension $\left(21 \times 10^{6}\right.$ of parathyrocytes) was injected via $18 \mathrm{G}$ needle into muscle transfascially (figure). Site selection for parathyroid allograft was conditioned by the absence of arteriovenous fistula on the side of the transplantation.

Generalized world experience of the parathyroid allotransplantation

\begin{tabular}{|c|c|c|c|c|c|}
\hline Author & Year & Allograft source & Recipient (N) & Result & IS \\
\hline W. Brown [2] & 1911 & $\begin{array}{l}\text { Cadaverous donor with } \\
\text { Bright's disease }\end{array}$ & After thyroidectomy (goiter) & $\begin{array}{l}\text { Minimum } 2 \\
\text { months }\end{array}$ & No \\
\hline H. Stone et al. [3] & 1934 & $\begin{array}{l}\text { Cultured parathyroid } \\
\text { cells of dead babies }\end{array}$ & $\begin{array}{l}\text { With congenital and } \\
\text { secondary HPT (5) }\end{array}$ & $\begin{array}{l}\text { In } 2 \text { out of } 5 \\
\text { patients }\end{array}$ & No \\
\hline J. Sterling et al. [4] & 1954 & Fetal PTG with vessels & With secondary HPT (3) & $\begin{array}{l}6,9 \text { and } 36 \\
\text { months }\end{array}$ & No \\
\hline E. Watkins et al. [5] & 1959 & $\begin{array}{l}\text { Fetal and infant PTG } \\
\text { on vascular "leg" }\end{array}$ & After thyroidectomy (3) & $\begin{array}{l}\text { Maximum } \\
\text { up to } 2 \text { years }\end{array}$ & No \\
\hline C. Groth et al. [6] & 1973 & $\begin{array}{c}\text { Donor with PTG } \\
\text { hyperplasia }\end{array}$ & With kidney transplant (1) & 21 months & No \\
\hline S. Wells et al. [7] & 1974 & $\begin{array}{l}\text { Living related PTG } \\
\text { donor (earlier - } \\
\text { kidney donor) }\end{array}$ & With kidney transplant (1) & $\begin{array}{l}\text { More than } 12 \\
\text { months }\end{array}$ & Да \\
\hline B. Duarte et al. [8] & 1985 & $\begin{array}{l}\text { Donor with PTG } \\
\text { hyperplasia and } \\
\text { cadaveric donor }\end{array}$ & $\begin{array}{l}\text { With kidney transplant and } \\
\text { two PTG allografts (1) }\end{array}$ & 10-16 months & No \\
\hline Q. Zeng et al. [9] & 1986 & $\begin{array}{c}\text { Fetal PTG on vascular } \\
\text { "leg" }\end{array}$ & $\begin{array}{c}\text { With primary and secondary } \\
\text { HPT (11) }\end{array}$ & $3-6$ years & Yes \\
\hline T. Kunori et al. [10] & 1991 & $\begin{array}{c}\text { Native }+ \text { cryopreserved } \\
\text { hyperplastic PTG } \\
\text { tissue }\end{array}$ & $\begin{array}{l}\text { With secondary HPT } \\
\text { and repeated PTG } \\
\text { transplantation }(1)\end{array}$ & $\begin{array}{l}\text { Reduction } \\
\text { of symptoms } \\
\text { and doses of } \\
\text { medicines }\end{array}$ & Yes \\
\hline E. Alfrey et al. [11] & 1992 & $\begin{array}{c}\text { Hyperplastic PTG } \\
\text { tissue }\end{array}$ & With kidney transplant (1) & 13 years & Yes \\
\hline G. Decker et al. [12] & 1995 & $\begin{array}{c}\text { Tissue of adenomatous } \\
\text { PTG in magnetic } \\
\text { microspheres }\end{array}$ & With secondary HPT (1) & $\begin{array}{l}\text { Partial } \\
\text { function }\end{array}$ & No \\
\hline C. Hasse et al. [13] & 1997 & $\begin{array}{c}\text { Hyperplastic PTG } \\
\text { tissue in microcapsules }\end{array}$ & $\begin{array}{l}\text { With secondary HPT (2), } \\
\text { from } 1 \text { donor }\end{array}$ & $\begin{array}{c}\text { PTH } \\
\text { normalization } \\
\text { in } 3 \text { weeks }\end{array}$ & No \\
\hline N. Torregrosa et al. [14] & 2005 & $\begin{array}{c}\text { Donor with PTG } \\
\text { hyperplasia }\end{array}$ & With kidney transplant (1) & 12 months & Yes \\
\hline T. Chapelle et al. [15] & 2009 & $\begin{array}{l}\text { PTG and kidney of } \\
\text { cadaveric donor }\end{array}$ & With kidney transplant (1) & 12 months & Yes \\
\hline P. Cabane et al. [16] & 2009 & $\begin{array}{l}\text { Microcapsules } \\
\text { with cryopreserved } \\
\text { hyperplastic PTG }\end{array}$ & With secondary HPT (1) & 8 months & No \\
\hline S. Flechner et al. [17] & 2010 & Cryopreserved PTG & With kidney transplant (1) & 11 months & Yes \\
\hline I. Belda et al. [18] & 2012 & $\begin{array}{c}\text { Donor with PTG } \\
\text { hyperplasia }\end{array}$ & With kidney transplant (1) & 2 years & Yes \\
\hline P. Giulianotti et al. [19] & 2014 & Living related donor & With kidney transplant (1) & 2 years & Yes \\
\hline R. Garcia-Roca et al. [20] & 2016 & Living related donor & With congenital HPT (1) & $\begin{array}{l}\text { More than } 9 \\
\text { months }\end{array}$ & Yes \\
\hline V. Khryshchanovich [21] & 2016 & $\begin{array}{l}\text { Macrocapsule with cells } \\
\text { of hyperplastic PTG }\end{array}$ & With secondary HPT (1) & 3 months & No \\
\hline
\end{tabular}




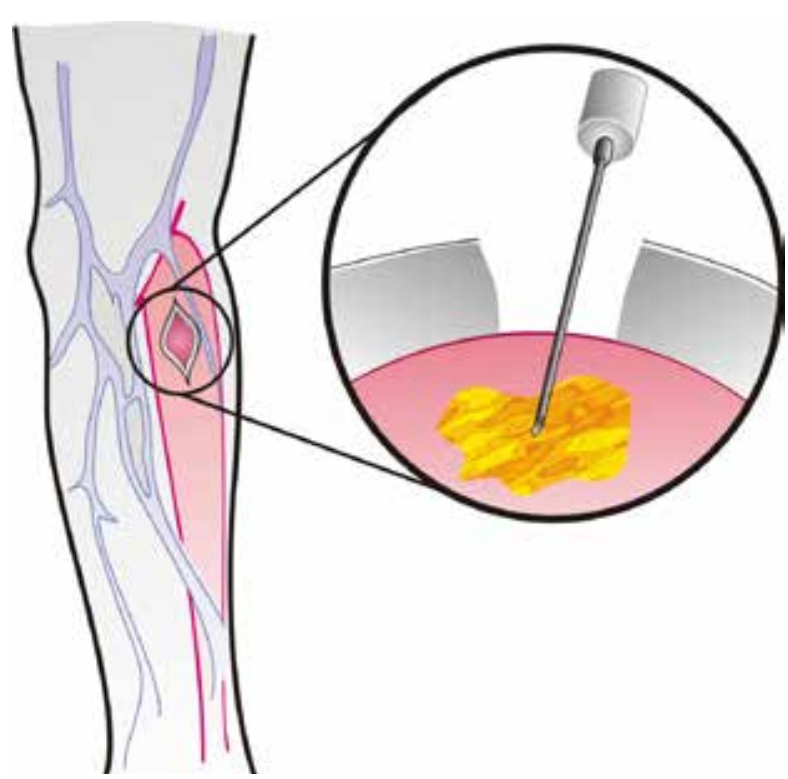

Figure. Schematic illustration of transplantation in the forearm muscles

Within the incisional period no complications, local and general side effects to the parathyroid cell allograft were registered. 1 month after the parathyroid cells transplantation, the clinicallaboratory compensation of hypoparathyroidism had occured (Table. 2). Cyclosporin concentration was $137 \mathrm{ng} / \mathrm{mL}$, urea $-15,8 \mathrm{mmol} / \mathrm{L}$, creatinine $147,2 \mathrm{mmol} / \mathrm{l}$, glomerular filtration rate $-38,7 \mathrm{~mL} /$ minute in blood. Within a 6-month observation period no convulsive syndrome manifested, Chvostek's and Trousseau's signs were stopped, the volume of oral substitution therapy reduced significantly (from 13-15 to 1-2 tablets), there was salt solutions that positively affected on increased physical activity and life quality of the recipient. 6 months after the transplantation the patient led a normal life and took per os $\mathrm{Ca} 0,5 \mathrm{~g} / \mathrm{day}$, which was a usual medicinal supplement in almost all patients with a functioning kidney transplant.

\section{Discussion}

The most common HPT cause is a surgical no need for parenteral administration of calcium

intervention in the neck region (mainly in case of thyroid gland pathology and PTG) or "non-surgical" PTG destruction after radiotherapy [23]. Congenital HPT occurs much less frequently, both alone and in combination with other metabolic disorders and anatomic abnormalities. However, regardless of etiology, clinical symptoms of hypocalcemia are similar, the severity of which due to its life-threatening potential varies from perioral numbness, paresthesia, muscle spasms to laryngospasm and tetany. A lifelong supplementation (calcium and vitamin D) will be required to patients, but often such therapy may not be manifested by a stable normalization of calcium homeostasis, because of their tendency to develop late complications. Nowadays, HPT replacement therapy with synthetic PTH has been developed - two injectable forms of parathyroid hormone, Natpara (I-84) and Forteo or teriparatide (I-34) are available for therapeutic use in the USA.

In January 2015, FDA (Food and Drug Administration) has approved the therapeutic use of PTH (I-84) as a daily subcutaneous injection. However, until now there is no experience of PTH (I-84) use in patients with a severe postoperative HPT and calcium-sensing receptor mutations. In addition, long-term use of Natpara is associated with a potential osteosarcoma risk. On the other hand, in accordance with FDA requirements, PTH (I-34) is used as therapy for osteoporosis and, having a short-term effects, requires multiple daily injections. It should be noted that both therapeutic options are still expensive (average wholesale price: Natpara $\$$ 4750 / month, of Forteo \$ 2111 / month), and the clinical effect depends on the patient's adherence to treatment. The use of portable PTH batchers in the form of so-called "portable pump" permitted to achieve more stable values of serum calcium [24].

Theoretically parathyroid allotranspantation could be an ideal therapeutic technique to restore a normal calcium homeostasis. Reports of a number of authors demonstrate good results of transplantation of a normal or hyperplastic PTG from living or cadaveric donors [2-22]. However, the need for lifelong immunosuppression significantly limits the clinical application of a similar approach.

Table 2 Dynamics of serum indices of calcium and parathyroid hormone and the volume of replacement therapy

\begin{tabular}{cccccc}
\hline Observation period & $\begin{array}{c}\text { Parathyroid } \\
\text { hormone, } \mathrm{pg} / \mathrm{mL}\end{array}$ & $\begin{array}{c}\mathrm{Ca}_{\text {total }}, \\
\mathrm{mmol} / \mathrm{l}\end{array}$ & $\begin{array}{c}\mathrm{Ca}_{\text {ionized., }}, \\
\mathrm{mmol} / \mathrm{l}\end{array}$ & $\begin{array}{c}\mathrm{Ca} \text { per os, } \\
\mathrm{g} / \mathrm{day}\end{array}$ & $\begin{array}{c}\text { Calcitriol, } \\
\mathrm{mcg} / \mathrm{day}\end{array}$ \\
\hline Prior transplantation & 1,7 & 1,71 & 0,98 & 4 & 1,25 \\
\hline 1 & \multicolumn{7}{c}{ The months after transplantation } \\
2 & 14,7 & 1,94 & 1,05 & 0,5 & 0,5 \\
3 & 32,7 & 2,58 & 1,38 & 0 & 0,25 \\
3,5 & no data & 2,4 & 1,29 & 0 & 0,25 \\
6 & 61,7 & 2,19 & 1,13 & 0 & 0,25 \\
\end{tabular}


In 1911, W. Brown [2] reported firstly about the transplantation of allogenic PTG to a young patient with a severe HPT, refractory to intravenous calcium asministration, occurred after the total thyroidectomy. Xenotransplantation of several PTG and thyroid glands has not brought any positive result and, ultimately, the patient was transplanted an allogenic PTG of a deceased donor. Before the implantation the parathyroid tissue was fragmented and was stored in saline at temperature $\left(32^{\circ} \mathrm{F}\right)$. At least within 4 months after surgery no HPT symptoms occurred.A little bit latter the attempts to treat the primary or congenital HPT by allotransplantation of small parathyroid fragments which required no immunosuppression has been made [3, 25]. Experimental studies were associated foremost with the study of the effectiveness of direct PTG revascularization [26]. The first clinical transplantation of the fetal thyroid-parathyroid complex by using a single "pedicle" anastomosis with the recipient common femoral artery was performed in 1954 [4]. Technical difficulties of the operation related to a small caliber of the anastomosed vessels were justified by less immunogenicity of a fetal transplant. The symptoms of tetany were stopped immediately following surgery and had not recurred within 12 months. Later such interventions had been used successfully in 12 of 14 patients within a 6-year follow-up [5, 9].

In 1973, C. Groth el al. [6] firstly described a case of a stable functioning of parathyroid allograft wthin 21 months in the patient, receiving immunosuppression on the regular basis following kidney transplantation. According to the authors, immunosuppressed patients with HPT after the organ transplantation appeared to be a "promising" parathyroid allograft recipients with a high probability of its long-term functioning. According to $\mathrm{N}$. Torregrosa et al. [14], the justified and legitimate source of PTG could be living unrelated donors, operated on for the parathyroid hyperplasia. There were reports in the recent literature concerning successful use of 1-2 PTG of healthy closely related donors (father, mother, sister), some of whom occasionally were kidney donors [7, 19, 20]. PTG retransplantation with a positive clinical effect was performed by B. Duarte et al. in the case of early dysfunction or failure of a "primary" parathyroid transplant [8].

Parathyroid tissue also expresses antigens of I and II classes of the major histocompatibility complex, which are capable inducing an immune response. To reduce the immunogenicity of donor material both in a clinic and in experiment, among the other approaches, the cultured parathyrocytes [3, 12, 21], HLA- "purified" microspheres [12], cryopreserved parathyroid tissue $[13,17,21]$; the technique of micro- and macroencapsulation [13, $16,21]$ and elimination leucocytes-"passengers" in the culture medium [27] were also applied for the transplantation (Table 1).

I. Nawrot et al. [28] presented the treatment results of 85 patients with postsurgical hypoparathyroidism, who underwent intramuscular allotransplantation of 20-30×106 cultured and cryopreserved parathyroid cells obtained from the donors with the secondary and tertiary hyperparathyroidism (retransplantation of parathyroid cells was required in 25 cases). As the experience of Polish colleagues showed [28], cryopreservation of parathyroid cells permitted to improve the results of clinical allotransplantation in the absence of immunosuppression: the average duration of the allograft functioning was 6.4 months. A. Saxe et al. found out that the freezing of parathyroid tissue reduced HLA expression on surface of parathyroid cells and their immunogenicity [29].

C. Hasse et al. [13] used firstly alginate microencapsulation technology in allotransplantation of parathyroid cells: 20 microspheres with parathyroid tissue were implanted into the forearm muscles to each of two patients with postsurgical hypoparathyroidism; functioning period of allograft was 3 months. According to the authors' data, the alginate microsphere provides a reliable barrier for molecules larger than $150 \mathrm{kDa}$, prevents the penetration of immunocompetent cells, immunoglobulins, complement components and, at the same time, provides the nutritional support for the transplant and free diffusion of parathyroid hormone in the blood. Immune mechanisms of rejection are based on the activation of $\mathrm{T}$ lymphocyte subpopulations, including CD8 +, whereas, a mechanical cell isolation in the microsphere prevents the interaction between the encapsulated tissue and the recipient's immune system [12].

Another immunoprotective approach is macroencapsulation of parathyroid cells based on the same principles [21]. The application of tissue and cell parathyroid encapsulation may be justified in patients with a severe hypocalcaemia who are not organ recipients, and, accordingly, require no "aggressive" immunosuppression.

The first successful multiorgan transplantation - kidney-pancreas and parathyroid tissue was performed in the patient with an autoimmune polyglandular syndrome and medullary cystic disease [30]. Within the insicional period a four-component immunosuppression was applied - anti-thymocyte globulin, azathioprine, cyclosporine, prednisone; and the parathyroid allograft functioning made up 2 years. N. Torregrosa et al. [14] reported about the case of a successful parathyroid allotransplantation in a 38-year-old patient with the anamnesis of 
kidney transplantion and total parathyroidectomy due to CKD and secondary hyperparathyroidism. Against the background of immunosuppressive therapy with corticosteroids, azathioprine and cyclosporine, the terms of therapeutic effect made up 2 years, and the peak concentration of PTH -34 $\mathrm{pg} / \mathrm{mL}$ was observed one year after the surgery. S. Flechner et al. [17] described another case of successful allotransplantation of cryopreserved parathyroid tissue into the humeroradial muscle of a 36-year-old man with the transplanted kidney. Just before the kidney transplantation due to the tertiary hyperparathyroidism the patient underwent subtotal, and then total parathyroidectomy with PTG autotransplantation into the deltoid muscle, which proved to be ineffective. In connection with the developed postoperative severe HPT (PTH 5 $\mathrm{pg} / \mathrm{mL}$ ) the patient was subjected to the re-allotransplantation of parathyroid tissue obtained from one and the same donor (a three-month interval). Duration of the allograft functioning was 11 months (PTH $15 \mathrm{pg} / \mathrm{mL}$ ) against the background of ongoing immunosuppression (tacrolimus, mycophenolate mofetil, steroids). Immunosuppression regime after kidney transplantation was sufficient to restore the PTH secretion, but information about the most preferred immunosuppressive drugs used in parathyroid allotransplantation is absent. According to S. Flechner et al. [17], the basic requirements to the source of the donor parathyroid tissue are the absence of antibodies to human immunodeficiency virus (HIV), hepatitis B and C, HLA phenotypes to which the recipient has already been sensitized; $\mathrm{ABO}$ compatibility, cryopreservation duration less than 1 year. However, in practice, it is rather difficult to apply a similar screening of the tissue typing due to the donor pool was limited by 4 donors.

Based on the available literature reports and the author's experience [21] in the present observation two complementary approaches were firstly used-immune alteration precultivation) of the parathyroid tissue of a living unrelated donor and recipient immunosuppressive therapy with the kidney transplant. Probably, the combined use of these methods of "avoidance" from the immune response has led to complete HPT compensation and has significantly extended the functional activity of parathyroid allograft.

\section{Conclusion}

Permanent hypoparathyroidism occurs in $1-2 \%$ of patients who underwent the surgeries on the thyroid gland or other organs of the neck, and it is characterized by hypocalcemia, low serum PTH levels and the presence of clinical symptoms within 6 months or more. Traditional HPT treat- ment involves a lifelong intake of "drug- intermediates" - calcium and vitamin D, but not of PTH and it explains insufficient effectiveness of drug therapy. In this connection, the search of new effective methods of HPT treatment is being carried out, including the use of transplant technologies. Parathyroid allotransplantation is considered to be a potentially promising treatment of HPT, however, the reaction of rejection still remains a major problem. Prolonged immunosuppression permits to extend allograft functional activity, but is able to cause a number of side effects and complications, and its application is scarcely justified in the case of transplantation therapy of "isolated" HPT. At the same time, a combined allotransplantation of the cadaveric kidney and cultured parathyroid cells isolated from the hyperplastic parathyroid tissue of a living unrelated donor is thought to be an effective treatment of severe permanent HPT in patients who need the organ transplantation with subsequent immunosuppressive therapy.

\section{The work was performed under the state innovation project "To develop and implement a method of surgical treatment of hypoparathyroidism" (State registration 20132515).}

\section{ЛИТЕРАТУРА}

1. Udelsman R. Six hundred fifty-six consecutive explorations for primary hyperparathyroidism. Ann Surg. 2002 May;235(5):665-70; discussion 670-72.

2. Brown WH. Parathyroid implantation in the treatment of tetania parathyreopriva. Ann Surg. 1911 Mar; 53(3):305-17.

3. Stone HB, Owings JC, Gey GO. Transplantation of living grafts of thyroid and parathyroid glands. Ann Surg. 1934 Oct; 100(4):613-28.

4. Sterling JA, Goldsmith R. Total transplant of thyroid gland using vascular anastomoses; report of successful result in chronic tetany. Surgery. 1954 Apr;35(Is 4):624-28. 5. Watkins EJr, Haynes LL, Adams HD. Aortic-pedicle technic for obtaining immediate vascularization of fetal parathyroidgland transplants in man; application in three patients with hypoparathyroidism appearing after thyroidectomy. $N$ Engl J Med. 1959 Jul 16;261(3):105-12.

6. Groth CG, Hammond WS, Iwatsuki S, Popovitzer M, Cascardo S, Halgrimson CG, et al. Survival of a homologous parathyroid implant in an immunosuppressed patient. Lancet. 1973 May 19;1(7812):1082-85.

7. Wells SA Jr, Burdick JF, Hattler BG, Christiansen C, Pettigrew HM, Abe M, et al. The allografted parathyroid gland: evaluation of function in the immunosuppressed host. Ann Surg. 1974 Dec;180(6):805-13.

8. Duarte B, Mozes MF, John E, Aronson I, Pollak $\mathrm{R}$, Jonasson $\mathrm{O}$. Parathyroid allotransplantation in the treatment of complicated idiopathic primary hypoparathyroidism. Surgery. 1985 Dec;98(6):1072-76.

9. Zeng Q. Allotransplantation of parathyroid glands to treat intractable hypoparathyroidism. Surgery. 1986 Jan;99(Is 1):131-32.

10. Kunori T, Tsuchiya T, Itoh J, Watabe S, Arai M, Satomi T, et al. Improvement of postoperative hypo- 
calcemia by repeated allotransplantation of parathyroid tissue without anti-rejection therapy. Tohoku $J$ Exp Med. 1991 Sep;165(1):33-40.

11. Alfrey EJ, Perloff LJ, Asplund MW, Dafoe DC, Grossman RA, Bromberg JS, et al. Normocalcemia thirteen years after successful parathyroid allografting in a recipient of a renal transplant. Surgery. 1992 Feb;111(2):234-36.

12. Decker GA, Stark JH, Botha JR, Margolius LP, Decker G. Allotransplantation of parathyroid cells. Lancet. 1995 Jan 14;345(8942):124.

13. Hasse C, Zielke A, KlöckG, Schlosser A, Zimmermann U, Rothmund M. Isotransplantation of microencapsulated parathyroid tissue in rats. Exp Clin Endocrinol Diabetes. 1997;105(1):53-56.

14. Torregrosa NM, Rodríguez JM, Llorente S, Balsalobre MD, Rios A, Jimeno L, et al. Definitive treatment for persistent hypoparathyroidism in a kidney transplant patient: parathyroid allotransplantation. Thyroid. 2005 Nov; 15(11):1299-302.

15. Chapelle T, Meuris K, Roeyen G, De Greef K, Van Beeumen G, Bosmans JL, et al. Simultaneous kidney-parathyroid allotransplantation from a single donor after 20 years of tetany: a case report. Transplant Proc. 2009 Mar;41(2):599-600. doi: 10.1016/j. transproceed.2008.12.026.

16. Cabané P, Gac P, Amat J, Pineda P, Rossi R, Caviedes R, et al. Allotransplant of microencapsulated parathyroid tissue in severe postsurgical hypoparathyroidism: a case report. Transplant Proc. 2009 Nov;41(9):387983. doi: 10.1016/j.transproceed.2009.06.211.

17. Flechner SM, Berber E, Askar M, Stephany B, Agarwal A, Milas M. Allotransplantation of cryopreserved parathyroid tissue for severe hypocalcemia in a renal transplant recipient. Am J Transplant. 2010 Sep;10(9):2061-65. doi: 10.1111/j.16006143.2010.03234.x.

18. Belda González I, del Moral JM, Pérez NM, Soto JB, Orihuela JA. Parathyroid allotransplantation as permanent treatment in a renal transplant patient. Cir Esp. 2012 Mar;90(3):202-3. doi: 10.1016/j. ciresp.2010.09.020. [Article in Spanish]

19. Giulianotti PC, D'Amico G, Tzvetanov I, Benedetti E. Living donor parathyroid allotransplantation with robotic transaxillary procurement in a kidney transplant recipient. Transpl Int. 2014 Jun;27(6):e43-5. doi: 10.1111 /ri. 12269 .

20. Garcia-Roca R, Garcia-Aroz S, Tzvetanov IG, Giulianotti PC, Campara M, Oberholzer J, et al. Simultaneous living donor kidney and parathyroid allotransplantation: first case report and review of literature. Transplantation. 2016 Jun;100(6):1318-21. doi: 10.1097/TP.0000000000001042.

21. Khryshchanovich V, Ghoussein Y. Allotransplantation of macroencapsulated parathyroid cells as a treatment of severe postsurgical hypoparathyroidism: case report. Ann Saudi Med. 2016 Mar-Apr;36(2):143-47. doi: 10.5144/0256-4947.2016.21.3.1130.

22. Al-Azem H, Khan AA. Hypoparathyroidism. Best Pract Res Clin Endocrinol Metab. 2012 Aug;26(4):51722. doi: 10.1016/j.beem.2012.01.004.

23. Winer KK, Zhang B, Shrader JA, Peterson D, Smith M, Albert PS, et al. Synthetic human parathyroid hormone 1-34 replacement therapy: a randomized crossover trial comparing pump versus injections in the treatment of chronic hypoparathyroidism. J Clin Endocrinol Metab. 2012 Feb;97(2):391-99. doi: 10.1210/ jc.2011-1908
24. Akers DR, Binkley EL, Miller AP. Homotransplantation of parathyroid gland in idiopathic hypoparathyroidism. Pediatrics. 1958 Jun;21(6):974-79.

25. Anikandrov BV, Yakovlev AY. Clinical experience in homotransplantation of thyroid and parathyroid glands on vascular stumps. Acta Chir Plast. 1966;8(1):23-31.

26. Sollinger HW, Mack E, Cook K, Belzer FO. Allotransplantation of human parathyroid tissue without immunosuppression. Transplantation. 1983 Dec;36(6):599-602.

27. Nawrot I, Woźniewicz B, Tołłoczko T, Sawicki A, Górski A, Chudziski W, et al. Allotransplantation of cultured parathyroid progenitor cells without immunosuppression: clinical results. Transplantation. 2007 Mar 27;83(6):734-40.

29. Saxe AW, Gibson G, Elfont E. In vitro assessment of parathyroid immunogenicity: the effect of cryopreservation. Surgery. $1990 \mathrm{Jul} ; 108(1): 56-62$.

30. Rahusen F, Munda R, Hariharan S, First MR, Demmy A. Combined kidney-pancreas and parathyroid transplantation: a case report. Clin Transplant. 1997 Aug;11(4):341-43.

\section{REFERENCES}

1. Udelsman R. Six hundred fifty-six consecutive explorations for primary hyperparathyroidism. Ann Surg. 2002 May;235(5):665-70; discussion 670-72.

2. Brown WH. parathyroid implantation in the treatment of tetania parathyreopriva. Ann Surg. 1911 Mar; 53(3): 305-17.

3. Stone HB, Owings JC, Gey GO. Transplantation of living grafts of thyroid and parathyroid glands. Ann Surg. 1934 Oct; 100(4): 613-28.

4. Sterling JA, Goldsmith R. Total transplant of thyroid gland using vascular anastomoses; report of successful result in chronic tetany. Surgery. 1954 Apr;35(Is 4):624-28. 5. Watkins EJr, Haynes LL, Adams HD. Aortic-pedicle technic for obtaining immediate vascularization of fetal parathyroidgland transplants in man; application in three patients with hypoparathyroidism appearing after thyroidectomy. $N$ Engl J Med. 1959 Jul 16;261(3):10512.

6. Groth CG, Hammond WS, Iwatsuki S, Popovitzer M, Cascardo S, Halgrimson CG, et al. Survival of a homologous parathyroid implant in an immunosuppressed patient. Lancet. 1973 May 19;1(7812):1082-85.

7. Wells SA Jr, Burdick JF, Hattler BG, Christiansen C, Pettigrew HM, Abe M, et al. The allografted parathyroid gland: evaluation of function in the immunosuppressed host. Ann Surg. 1974 Dec;180(6):805-13.

8. Duarte B, Mozes MF, John E, Aronson I, Pollak $\mathrm{R}$, Jonasson O. Parathyroid allotransplantation in the treatment of complicated idiopathic primary hypoparathyroidism. Surgery. 1985 Dec;98(6):1072-76.

9. Zeng Q. Allotransplantation of parathyroid glands to treat intractable hypoparathyroidism. Surgery. 1986 Jan;99(Issue 1):131-32.

10. Kunori T, Tsuchiya T, Itoh J, Watabe S, Arai M, Satomi T, et al. Improvement of postoperative hypocalcemia by repeated allotransplantation of parathyroid tissue without anti-rejection therapy. Tohoku $J$ Exp Med. 1991 Sep;165(1):33-40.

11. Alfrey EJ, Perloff LJ, Asplund MW, Dafoe DC, Grossman RA, Bromberg JS, et al. Normocalcemia thirteen years after successful parathyroid allografting in a recipient of a renal transplant. Surgery. 1992 Feb;111(2):234-36.

12. Decker GA, Stark JH, Botha JR, Margolius LP, 
Decker G. Allotransplantation of parathyroid cells. Lancet. 1995 Jan 14;345(8942):124.

13. Hasse C, Zielke A, Klöck G, Schlosser A, Zimmermann $U$, Rothmund $M$. Isotransplantation of microencapsulated parathyroid tissue in rats. Exp Clin Endocrinol Diabetes. 1997;105(1):53-56.

14. Torregrosa NM, Rodríguez JM, Llorente S, Balsalobre MD, Rios A, Jimeno L, et al. Definitive treatment for persistent hypoparathyroidism in a kidney transplant patient: parathyroid allotransplantation. Thy roid. 2005 Nov; 15(11):1299-302.

15. Chapelle T, Meuris K, Roeyen G, De Greef K, Van Beeumen G, Bosmans JL, et al. Simultaneous kidney-parathyroid allotransplantation from a single donor after 20 years of tetany: a case report. Transplant Proc. 2009 Mar;41(2):599-600. doi: 10.1016/j. transproceed.2008.12.026.

16. Cabané P, Gac P, Amat J, Pineda P, Rossi R, Caviedes R, et al. Allotransplant of microencapsulated parathyroid tissue in severe postsurgical hypoparathyroidism: a case report. Transplant Proc. 2009 Nov;41(9):387983. doi: 10.1016/j.transproceed.2009.06.211.

17. Flechner SM, Berber E, Askar M, Stephany B, Agarwal A, Milas M. Allotransplantation of cryopreserved parathyroid tissue for severe hypocalcemia in a renal transplant recipient. Am J Transplant. 2010 Sep;10(9):2061-65. doi: 10.1111/j.16006143.2010.03234.x.

18. Belda González I, del Moral JM, Pérez NM, Soto JB, Orihuela JA. Parathyroid allotransplantation as permanent treatment in a renal transplant patient. Cir Esp. 2012 Mar;90(3):202-3. doi: 10.1016/j. ciresp.2010.09.020. [Article in Spanish]

19. Giulianotti PC, D'Amico G, Tzvetanov I, Benedetti E. Living donor parathyroid allotransplantation with robotic transaxillary procurement in a kidney transplant recipient. Transpl Int. 2014 Jun;27(6):e43-5. doi: $10.1111 /$ tri. 12269 .

20. Garcia-Roca R, Garcia-Aroz S, Tzvetanov IG, Giulianotti PC, Campara M, Oberholzer J, et al. Simultaneous living donor kidney and parathyroid al-

\section{Адрес для корреспонденции}

220116, Республика Беларусь,

г. Минск, пр-т Дзержинского, д. 83,

УО «Белорусский государственный

медицинский университет»,

2-я кафедра хирургических болезней,

тел.раб.: + 37517 287-86-52,

факс: + 37517 201-91-60,

e-mail: vladimirkh77@mail.ru,

Хрыщанович Владимир Янович

\section{Сведения об авторах}

Хрыщанович В.Я., д.м.н., доцент, доцент 2-й кафедры хирургических болезней УО «Белорусский государственный медицинский университет».

Вершинин П.Ю., заведующий отделением нефрологии и гемодиализа УЗ «9-я городская клиническая больница» г. Минска.

Большов А.В., к.м.н., доцент, доцент 2-й кафедры хирургических болезней УО «Белорусский государственный медицинский университет».

Третьяк С.И., Заслуженный деятель науки Республики Беларусь, д.м.н., профессор, член- lotransplantation: first case report and review of literature. Transplantation. 2016 Jun;100(6):1318-21. doi: 10.1097/TP.0000000000001042.

21. Khryshchanovich V, Ghoussein Y. Allotransplantation of macroencapsulated parathyroid cells as a treatment of severe postsurgical hypoparathyroidism: case report. Ann Saudi Med. 2016 Mar-Apr;36(2):143-47. doi: $10.5144 / 0256-4947.2016 .21 .3 .1130$.

22. Al-Azem H, Khan AA. Hypoparathyroidism. Best Pract Res Clin Endocrinol Metab. 2012 Aug;26(4):51722. doi: 10.1016/j.beem.2012.01.004.

23. Winer KK, Zhang B, Shrader JA, Peterson D, Smith M, Albert PS, et al. Synthetic human parathyroid hormone 1-34 replacement therapy: a randomized crossover trial comparing pump versus injections in the treatment of chronic hypoparathyroidism. J Clin Endocrinol Metab. 2012 Feb;97(2):391-99. doi: 10.1210/ jc.2011-1908.

24. Akers DR, Binkley EL, Miller AP. Homotransplantation of parathyroid gland in idiopathic hypoparathyroidism. Pediatrics. 1958 Jun;21(6):974-79.

25. Anikandrov BV, Yakovlev AY. Clinical experience in homotransplantation of thyroid and parathyroid glands on vascular stumps. Acta Chir Plast. 1966;8(1):23-31. 26. Sollinger HW, Mack E, Cook K, Belzer FO. Allotransplantation of human parathyroid tissue without immunosuppression. Transplantation. 1983 Dec;36(6):599602.

27. Nawrot I, Woźniewicz B, Tołłoczko T, Sawicki A, Górski A, Chudziski W, et al. Allotransplantation of cultured parathyroid progenitor cells without immunosuppression: clinical results. Transplantation. 2007 Mar 27;83(6):734-40.

29. Saxe AW, Gibson G, Elfont E. In vitro assessment of parathyroid immunogenicity: the effect of cryopreservation. Surgery. 1990 Jul;108(1):56-62.

30. Rahusen F, Munda R, Hariharan S, First MR, Demmy A. Combined kidney-pancreas and parathyroid transplantation: a case report. Clin Transplant. 1997 Aug;11(4):341-43.

\section{Address for correspondence}

220116, the Republic of Belarus,

Minsk, Dzerzhinski str., 83,

EE «Belarusian State Medical University»,

Department of surgical diseases N2.

Tel.: +375 17 287-86-52

Fax: + 37517 201-91-60

E-mail: vladimirkh77@mail.ru

Vladimir Y. Khryshchanovich

\section{Information about the authors}

Khryshchanovich V.Y. MD, Ass. Professor of the department of the surgical diseases N2, EE «Belarusian State Medical University».

Vershinin P.Y. Head of the nephrology and hemodyalysis unit, ME «The $9^{\text {th }}$ City Clinical Hospital», Minsk.

Bolshov A.V. PhD, Ass. Professor of department of the surgical diseases N2, EE «Belarusian State Medical University».

Tretyak S.I. Honored Worker of Science of the Republic of Belarus, MD, Professor, Corresponding Member of NAS of Belarus, Head of department of the surgical 
корреспондент НАН Беларуси, заведующий 2-й кафедрой хирургических болезней УО «Белорусский государственный медицинский университет».

Кузьменкова Е.И., заведующая эндокринологическим отделением ГУ «Республиканский центр медицинской реабилитации и бальнеолечения».

Писаренко А.М., заведующий отделением опухолей головы и шеи УЗ «Минский городской клинический онкологический диспансер».

Ходосовская Е.В., старший научный сотрудник лаборатории биохимических методов исследования НИЧ УО «Белорусский государственный медицинский университет».

Колесникова Т.С., старший научный сотрудник лаборатории биохимических методов исследования НИЧ УО «Белорусский государственный медицинский университет».

Руммо O.O., Заслуженный врач Республики Беларусь, д.м.н., профессор, заместитель главного врача по хирургии У3 «9-я городская клиническая больница» г. Минска, главный внештатный трансплантолог МЗ РБ.

Поступила 1.07.2016 г.

Принята в печать 12.09.2016 г. diseases N2, EE «Belarusian State Medical University». Kuzmenkova E.I. Head of the endocrinology unit, SE «Republican Center of Medical Rehabilitation and Balneotherapy».

Pisarenko A.M. Head of department of the head and neck tumors, ME «Minsk City Clinical Oncologic Dispensary».

Khodosovskaya E.V. Senior researcher of the laboratory of biochemical research methods subdivision, EE «Belarusian State Medical University».

Kolesnikova T.S. Senior researcher of the laboratory of biochemical research methods subdivision, EE «Belarusian State Medical University».

Rummo O.O. Honored Worker of Science of the Republic of Belarus, MD, professor, Deputy Chief of surgery, ME «The $9^{\text {th }}$ City Clinical Hospital», Minsk, Chief freelance transplantologist of the Ministry of Health, the Republic of Belarus.

Received 1.07.2016

Accepter 12.09.2016 